\title{
Early Cretaceous arthropods from plattenkalk facies in Mexico
}

\author{
F.J. Vega ${ }^{1}$, P. Garcia-Barrera ${ }^{2}$, M. Coutiño ${ }^{3}$, T. Nyborg ${ }^{4}$, P. Cifuentes-Ruiz ${ }^{1}$, K. González-Rodríguez ${ }^{5}$,
} A. Martens ${ }^{6}$, C.R. Delgado ${ }^{7}$ \& G. Carbot ${ }^{3}$

${ }^{1}$ Instituto de Geología, UNAM, Ciudad Universitaria, Coyoacán, México D. F. 04510, México; ${ }^{2}$ Facultad de Ciencias, UNAM, Ciudad Universitaria, Coyoacán, México D. F. 04510, México; ${ }^{3}$ Museo de Paleontología, Instituto de Historia Natural y Ecología, Calzada de los Hombres Ilustres s/n, Tuxtla Gutiérrez, Chiapas 29000, México; ${ }^{4}$ Department of Natural Sciences, Loma Linda University, Loma Linda, CA 92350, USA; ${ }^{5}$ Museo de Paleontología, Centro de Investigaciones Biológicas, Universidad Autónoma del Estado de Hidalgo, Km 4.5 Carretera Pachuca-Tulancingo, C.P. 42184 Pachuca, Hidalgo, México; ${ }^{6} Z$ warteweg $76^{a}$, NL2511 VV Den Haag, the Netherlands; ${ }^{7}$ Departamento de Paleontología, SEPC-MUDE. Prol. Pérez Treviño 3745, Parque Las Maravillas, C.P. 25015, Saltillo, Coahuila, México

Keywords: Cretaceous, plattenkalk, Arthropoda, Mexico

\begin{abstract}
Several well-preserved arthropod faunas have been studied in Mexico during the past few years. The purpose of the present note is to outline advances in the study of these arthropods and of their paleoenvironmental implications, from four localities. The age for these localities ranges from the Early to the Late Cretaceous. At most of these localities lithographic limestones crop out, with fish remains representing the most attractive element of study. However, arthropods constitute a very important tool for reconstructing paleoenvironment (marine crustaceans, freshwater and terrestrial insects and arachnids). Detailed studies of these assemblages will aid in our understanding of ancient coastal dynamics and the paleoecology of these unique environments.
\end{abstract}

\section{Tepexi de Rodríguez, Puebla}

This locality is famous for the exceptionally wellpreserved and diverse reef fish fauna (Applegate, 1995). The diversity here is remarkable; on record are reptilian remains (lizard, turtle, crocodile, pterosaur), foraminifera, sponges, corals, ammonites, belemnites, gastropods, bivalves, holothurians, asteroids, ophiuroids, echinoid ossicles, and even a fungus (Applegate, 1987). A middle to late Albian age has been suggested for the red lithographic limestone of the Tlayúa Formation (Seiberz and Buitrón, 1987). Arthropods are represented by an unidentified insect wing, a dragonfly nymph, one species of arachnid, one species of isopod, and two species of decapods (Feldmann et al., 1998). It is im- portant to note that most of the brachyuran remains represent molts, while none of the numerous isopods appear to be. Morphology of the isopod species resembles-modern fish parasites. It seems probable these isopods and fish were associated, both getting trapped in the freshwater environment during a particular (storm) event. Recent isotopic studies have revealed that the Tepexi lithographic limestone was deposited in a freshwater environment, with periodic marine influence, and that a reef was proximal to this marginal environment (Guerrero-Arenas et al,, 2002).

\section{Zimapán, Hidalgo}

The Cerro Muhi quarry exposes the Trancas Formation of laminar limestone, of probable Cenomanian age, with foraminifera, ammonites, crinoids, echinoids, and a diverse ichthyofauna (GonzálezRodríguez, 2002; González-Rodríguez and Applegate, 2000; González-Rodríguez et al., 2000). Several mecochirid specimens are under study. One specimen is provisionally assigned to Linuparus. Due to its relatively recent discovery, the Muhi quarry has furnished comparatively limited material so far. 


\section{Rincón Colorado, Coahuila}

This locality is famous for its abundant and diverse dinosaur remains. Coprolites, tortoise bones, freshwater gastropods, bivalves, angiosperm fruits and leaves are abundant at certain horizons (Rodríguezde la Rosa and Cevallos-Ferriz, 1994; 1995; 1998). A complete specimen and an isolated leg of a blattoid (cockroach), a small spider (Salticidae?) of less than $1 \mathrm{~mm}$, and a partial wing of dragonfly have recently been collected from clay beds of the early Maastrichtian Cerro del Pueblo Formation. Diverse palm and other angiosperm leaves were found within the same layer. A more detailed study of these arthropods will contribute to the paleoecological setting providing a unique opportunity to look at the association of arthropods and an abundant dinosaur fauna at this locality in NE Mexico.

\section{El Espinal, Chiapas}

A series of quarries exposing laminated dolomite, located northwest of Tuxtla Gutiérrez, Chiapas, has produced vegetable matter, a few gastropods, small bivalves, and a rare fish fauna (González-Rodríguez et al., 2002; Ovalles and Alvarado, 2002). A late Aptian-early Albian age is suggested for this part of the Sierra Madre Formation, based on lateral biostratigraphic correlation (Michaud, 1987). Fossiliferous limestone of the upper unit of the Sierra Madre Formation contains the foraminifer Nummoloculina heimi, of Albian-Cenomanian age (Steele and Waite, 1985). Locals have exploited the quarries informally, and thus no complete exposure of the section has been studied. The quarry became of interest to local paleontologists on account of its fossil fish yield. However, their remains seem to be scarce in comparison to other localities. This may be due to less intensive working at the quarry. No microfossils have been found, except for a few ostracode remains. However, the abundance of tanaidaceans is remarkable. Horizons with hundreds of specimens could be followed laterally, suggesting mass mortality events. A single species of tanaidacean is recognized, and reconstruction is possible based on some well-preserved specimens. Other horizons contain isopods, of which two species have been identified. A single, almost complete molt of Palinurus has also been collected, as well as a pair of pagurid chelae. Finally, a well-preserved specimen of odonate nymph is part of the assemblage. However, it appears that only one group is present at each horizon. Although the presence of diagnostic terrestrial and freshwater elements clearly suggests a freshwater/brackish water environment, the abundance and good preservation of tanaidaceans suggest more marine conditions. Tanaidaceans are very sensitive to environmental changes, especially when oxygen concentrations fluctuate. It is important to note that the pagurid and Palinurus are represented by molts, but the state of preservation of the molt of the first is remarkable, suggesting little or no transport at all. Although arthropod material seems to be enough to complete the first formal contribution for this locality, more work is needed in order to define the paleoenvironment of this new, and potentially diverse, locality in southern Mexico.

\section{Conclusions}

It seems that the Aptian/Albian-Cenomanian was an important time interval in Mexico, with the deposit of several mixed environments along the eastern part of the territory. Study of the fossils preserved at these localities allows a unique opportunity to describe these mixed marine, freshwater and terrestrial elements, of which only the arthropods are represented as a group across all three. Unfortunately, the frequency of finds in lithographic limestone quarries depends directly on the intensity of work, and preservation of specimens is also dependent of educating the people in charge of the quarry. From the above-mentioned localities, only Tepexi de Rodríguez has been supported institutionally in order to preserve this national inheritance. We may never know how many important specimens have been destroyed or sold through ignorance or by necessity. The only way to protect these treasures is to bring them to light, and hope that people will understand their scientific value to our and future generations. 


\section{References}

Applegate SP. 1987. A preliminary study of the Tlayula Quarry near Tepexi de Rodríguez, Puebla. Revista de la Sociedad mexicana de Paleontologia 1: 40-45.

Applegate SP. 1995. An overview of the Cretaceous fishes of the quarries near Tepexi de Rodriguez, Puebla, México. In Arratia, and G. Viohl (eds.), Mesozoic Fishes-Systematics and Paleoecology. Munich, Germany, 529-538.

Feldmann RM, Vega FJ, Applegate SP, Bishop GA. 1998. Early Cretaceous arthropods from the Tlayúa Formation at Tepexi de Rodriguez, Puebla, Mexico. Jour. Paleo. 72: 79-90.

González-Rodriguez K. 2002. Paleoictiofauna de la Cantera Muhi en Zimapán, Hidalgo. VIII Congreso Nacional de Paleontologia, Sociedad Mexicana de Paleontologia. Guadalajara, Jalisco, Méxíco, 109.

González-Rodríguez K, Applegate SP. 2000. Muhì Quarry, a now Cretaceous fish locality in Central Mexico. 60th Annual Meeting, Soc. Vert. Paleont, Jour. Vert. Paleo. 20: 45A.

González-Rodríguez K, Moreno-Tovar R, Vega FJ. 2000. Zimapán, una nueva localidad Cretácica marina en el Estado de Hidalgo, México. VII Congreso Nacional de Paleontología, Sociedad Mexicana de Paleontología. Linares, Nuevo León, 35-36.

González-Rodríguez $\mathbf{K}$, García-Barrera $\mathbf{P}$, Avendaño J. 2002. Un nuevo registro de la Familia Macrosemidae (Neopterygii-Halecostomi) en Chiapas, sureste de México. XVI Convención Geológica Nacional. Libro de Resúmenes, Puerto Vallarta, México, 303.

Guerrero-Arenas R, Garcia-Barrera P, Centeno-García E, Morales-Puente P, Cienfuegos-Alvarado E. 2002.
Nuevos datos paleoambìentales de la Cantera Tlayúa en Tepexi de Rodríguez, Puebla, Méxìco. XVI Convención Geológica Nacional. Libro de Resúmenes, Puerto Vallarta, México. 306-307.

Michaud F. 1987. Stratigraphie et paleogeographie du Mesozoique du Chiapas (Sud Est du Mexique). These du Doctorat. Universite Paris 6. France, 1- 298.

Ovalles DE, Alvarado OJ. 2002. Los paracuplếidos de la Cantera El Espinal, Ocozocuautla de Espinosa, Chiapas. VIII Congreso Nacional de Paleontología. Libro de Resúmenes, Guadalajara, México, 120.

Rodríguez de la Rosa R, Cevallos Ferriz SRS. 1994. Upper * Cretaceous zingiberlean fruits with in situ seeds from Southeastern Coahuila, México. Inter. Jour. Plant Sci. 155: 786-805.

Rodríguez de la Rosa R, Cevallos Ferriz SRS. 1995. Plantbearing coprolites from the El Cerro del Pueblo Formation, southeastern Coahuila. Amer. Jour. Botany (SuppL) 82: 260.

Rodríguez de la Rosa R, Cevallos Ferriz SRS. 1998. Vertebrates of the El Pelillal Locality (Campanian, Cerro del Pueblo Formation), southeastern Coahuila, México. Jour. Vert. Paleo, 18: 751-764.

Selberz E, Buitrón BE. 1987. Investìgaciones paleontológicas y su aṕlicación bioestratigráfica de los Neohibolites de Tepexi de Rodríguez, Edo. de Puebla (Albiano, Cretácico medio, México). In Barbarín-Castillo JM, Gurski HJ, Meiburg P, eds. El Cretăcico de México y América Central, Univversídad Autónoma de Nuevo Leốn, Facultad de Ciencias de La Tierra, Actas 2, 121-124.

Steele, RD, White EL. 1985. Contributions to the stratigraphy of Sierra Madre Limestone (Cretaceous) of Chiapas. Universidad Nacional Autónoma de México, Instituto de Geologia, Boletin 102: 1-175. 